\title{
A multiproxy peat record of Holocene mangrove palaeoecology from Twin Cays, Belize
}

\author{
Matthew J. Wooller, ${ }^{1 *}$ Rebecca Morgan, ${ }^{2}$ Sarah Fowell, ${ }^{2}$ Hermann \\ Behling ${ }^{3}$ and Marilyn Fogel ${ }^{4}$
}

\author{
( ${ }^{1}$ Alaska Stable Isotope Facility, Water and Environmental Research Center and School of Fisheries \\ and Ocean Sciences, Duckering Building, University of Alaska Fairbanks, Alaska 99775, USA; \\ ${ }^{2}$ Department of Geology and Geophysics, University of Alaska Fairbanks, Box 755780, Fairbanks \\ Alaska, 99775, USA; ${ }^{3}$ Department of Palynology and Climate Dynamics, Albrecht-von-Haller-Institute \\ for Plant Sciences, University of Göttingen, Untere Karspüle 2, 37073 Göttingen, Germany; \\ ${ }^{4}$ Geophysical Laboratory, Carnegie Institution of Washington, 5251 Broad Branch Road, NW \\ Washington DC 20015-1305, USA)
}

Received 8 January 2007; revised manuscript accepted 19 June 2007

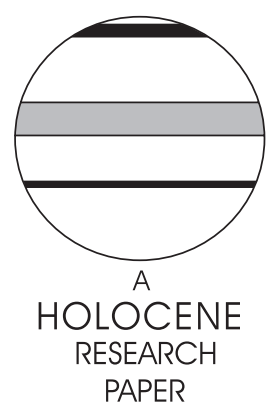

\begin{abstract}
The extent and function of coastal mangrove ecosystems are likely to be influenced by future changes in sea level. Multiple proxies of past mangrove ecosystems preserved in a $780 \mathrm{~cm}$ long peat core (TCC2) taken from Twin Cays, Belize, record palaeoecological changes since $\sim 8000$ cal. yr BP. The proxies included pollen and the stable-isotope (C, N and $\mathrm{O}$ ) compositions of mangrove leaf fragments. Rhizophora mangle (red mangrove) has been dominant at this site on Twin Cays for over $\sim 8000$ years. Variations in $\delta^{13} \mathrm{C}$ and $\delta^{15} \mathrm{~N}$ suggest past changes in stand structure between dwarf, transition and tall $R$. mangle through the Holocene. Marked changes in the $\delta^{18} \mathrm{O}$ (up to $\sim 4 \%$ ) of mangrove leaf fragments throughout TCC 2 most likely record variations in the proportion of seawater versus precipitation taken up by past mangroves, reflecting the degree of inundation of the site with seawater resulting from changes in the rate of Holocene sea-level rise. Notably, a decline in peat accumulation rate at $\sim 7200$ cal. yr BP correlates with a decrease in the rate of rise in sea level. This was not accompanied by a marked change in the pollen assemblages. However, changes in assemblage composition began to occur $\sim 6300$ cal. yr BP, with an increase in Myrsine-type and Avicennia germinans (black mangrove) pollen. An increase in the $\delta^{18} \mathrm{O}$ between 6100 and $5300 \mathrm{cal}$. yr BP, which correlates with other records from Central America, indicates a significant increase in the rate of rise in sea level.
\end{abstract}

Key words: Palaeoecology, mangroves, Holocene, stable isotopes, pollen, oxygen, carbon, nitrogen, Belize.

\section{Introduction}

Mangrove ecosystems perform significant roles in global carbon cycling (Chmura et al., 2003; Dittmar et al., 2006) and in protecting tropical and subtropical coastlines from disturbances such as tsunamis (Kathiresan and Rajendran, 2005; Danielsen et al., 2005). The extent and function of mangrove ecosystems present along tropical coastlines are likely to be significantly influenced by fluctuations in sea level (Blasco, 1984; Woodroffe, 1995b; Ellison and Farnsworth, 1997; Swarzbach, 1999). These can be short-term (episodic) changes,

*Author for correspondence (e-mail: ffmjw@uaf.edu) such as flooding associated with tsunamis (Kathiresan and Rajendran, 2005; Danielsen et al., 2005) and hurricanes, or longer-term changes associated with fluctuations in sea level resulting from global environmental changes, such as arctic warming (Arctic Monitoring and Assessment Programme (AMAP) et al., 2004). Although episodic changes can be studied by examining recent past events (eg, Danielsen et al., 2005; Maa et al., 2006; Piou et al., 2006) and by conducting laboratory or manipulative field-based experiments (eg, Ellison and Farnsworth, 1997), it is more difficult to examine mangrove responses to more gradual or longer-term changes in sea level. This challenge is compounded by potential spatial variability (eg, local habitat versus regional ecosystem). 
Documented changes in sea level of the Caribbean region during the Holocene (Blanchon and Shaw, 1995; Toscano and Macintyre, 2003; Gischler and Hudson, 2004; Blanchon, 2005; Gischler, 2006) show that the rate of rise in sea level was greatest prior to $\sim 7000$ calendar years before present (cal. yr BP) and then diminished after this time. 'Stepped' increases in the rate of rise in sea level may also have occurred during the Holocene (Blanchon and Shaw, 1995; Blanchon, 2005). Some records from Central and South America have been interpreted as evidence of falling sea level during this period (Jacob and Hallmark, 1996; Wooller et al., 2004a; Angulo et al., 2006). However, a comprehensive review of evidence from the Brazilian coast shows that although the rate of rise in sea level during the Holocene may have slowed at times, it is unlikely that sea level substantially dropped (Angulo et al., 2006).

Studies of Holocene palaeoenvironments of Belize and other parts of Central America have largely focused on mainland sites (Leyden, 1987; Alcalaherrera et al., 1994; Hodell et al., 1995; Jacob and Hallmark, 1996; Whitmore et al., 1996; Curtis et al., 1998). Findings from these studies have been related to Mayan population dynamics (eg, Jacob and Hallmark, 1996; Islebe et al., 1996; Curtis et al., 1998) and changes in sea level (eg, Alcalaherrera et al., 1994; Hodell et al., 1995; Jacob and Hallmark, 1996). In some instances, sea-level variability has indirectly complicated limnological interpretations at mainland sites by influencing the levels of phreatic aquifers (eg, Alcalaherrera et al., 1994; Hodell et al., 1995; Jacob and Hallmark, 1996). For instance, the relative rise in Holocene sea level seems to have been the main control on mainland lagoonal stratigraphy in lowland northern Belize (Alcalaherrera et al., 1994). Despite the relevance of coastal ecosystems to the Mayan civilization in Belize (McKillop, 2002, 2005), few studies of mangrove palaeoecology (eg, McKee and Faulkner, 2000a; Wooller et al., 2004a) have been conducted along the coasts of Belize.

We discuss pollen and stable isotope $(\mathrm{C}, \mathrm{N}$ and $\mathrm{O})$ data from a $780 \mathrm{~cm}$ peat core (TCC2) from Twin Cays in the light of evidence from a previous Twin Cays core (TCC1) (Wooller et al., 2004a), Holocene changes in sea level (Blanchon and Shaw, 1995; Toscano and Macintyre, 2003; Gischler and Hudson, 2004; Blanchon, 2005; Gischler, 2006) and Central American palaeoenvironmental changes. Pollen and stable carbon and nitrogen isotope analyses of mangrove peat cores are useful to track past changes in mangrove floral composition (Behling and da Costa, 2001; Behling et al., 2001; Wooller et al., 2004a), stand structure and nutrient limitation (Wooller et al., 2003b, 2004a). In addition to these analyses, we investigate the analyses of two novel proxies: stable-oxygen-isotope composition of mangrove leaf fragments and relative peat hardness (penetrometer analyses).

The $\delta^{18} \mathrm{O}$ of organic matter in plant leaves is primarily influenced by the $\delta^{18} \mathrm{O}$ of the water available to a plant, in addition to some physiological mechanisms (eg, evapotranspiration) and environmental conditions (eg, humidity and temperature) (Sauer et al., 2001; McCarroll and Loader, 2004). A number of studies have been devoted to understanding the relationship between the $\delta^{18} \mathrm{O}$ of source water in mangrove habitats and the $\delta^{18} \mathrm{O}$ of mangroves (Sternberg and Swart, 1987; Lin and Sternberg, 1993, 1994; Verheyden et al., 2004). These studies have included investigations of the relationship between the $\delta^{18} \mathrm{O}$ of source water and the $\delta^{18} \mathrm{O}$ of stem water, in addition to the relationship between source water and organically bound oxygen (ie, cellulose) in mangrove species (eg, Avicennia germinans and Rhizophora mangle). Mangroves in southern Florida growing in close proximity to ocean water had stem water with a $\delta^{18} \mathrm{O}$ that reflected that of the ocean water, while those less frequently inundated with ocean water had relatively lower $\delta^{18} \mathrm{O}$ values indicating that they were using proportionally more rainwater (Sternberg and Swart, 1987). Ishshalomgordon et al., (1992) subsequently grew groups of mangroves that were supplied with water with the same $\delta^{18} \mathrm{O}$ value and a range of different salinities. They found no significant difference in the $\delta^{18} \mathrm{O}$ of leaves from trees grown at different salinities; the $\delta^{18} \mathrm{O}$ of the leaf organic matter reflected the $\delta^{18} \mathrm{O}$ of the source water. They concluded that the $\delta^{18} \mathrm{O}$ values of cellulose in $R$. mangle leaves are a faithful recorder of the $\delta^{18} \mathrm{O}$ changes in water associated with sea water intrusion and therefore rates of change in sea level. Since mangroves seem to depend on water in the surface layers of the substrates in which they grow as their primary water source, and there is no fractionation in oxygen isotopes during water uptake by mangrove roots (Lin and Sternberg, 1994), it seems plausible that the $\delta^{18} \mathrm{O}$ of mangrove subfossils (ie, leaf fragments and tree rings) could be an effective indicator of the $\delta^{18} \mathrm{O}$ of past surface waters, as previously suggested by Ishshalomgordon et al. (1992) and Sternberg and Swart (1987).

Although the difference in $\delta^{18} \mathrm{O}$ between ocean water and precipitation in the tropics is not as large as it is at high latitudes (Bowen et al., 2005), rainfall in the tropics tends to have morenegative $\delta^{18} \mathrm{O}$ values $(<0 \%$ ) relative to standard mean ocean water (0\%) (Benway and Mix, 2004; Bowen et al., 2005; Curtis et al., 1998). These isotopic differences can be reflected in the $\delta^{18} \mathrm{O}$ of mangroves depending on the relative proportions of ocean water versus rainfall (Ishshalomgordon et al., 1992). There are also no reasons to suspect significant changes in the past water source and history of water-vapour transport in Central America during the early Holocene relative to today (Curtis et al., 1998).

Although mangroves can exist in saline environments, they can also exist in fresh water as facultative halophytes (Sternberg and Swart, 1987). We acknowledge that interpreting $\delta^{18} \mathrm{O}$ analyses of plant organic matter can be challenging when considered in isolation (McCarroll and Loader, 2004), so we conducted these analyses within a multiproxy approach (McCarroll and Loader, 2004). An initial examination of the past $\delta^{18} \mathrm{O}$ of mangrove leaf fragments is thus presented in the light of the other palaeoecological proxies. In this context, we also present a measure of the relative hardness and softness of the peat, acquired with a penetrometer. Mangrove peat can present a notoriously subtle stratigraphy, with very little variation in colour and minor variation in texture. The penetrometer data is a means of measuring peat hardness that might allow future correlation between independent cores from the region.

\section{Study site}

Twin Cays is composed of two islands, the west and east island, located $\sim 12 \mathrm{~km}$ from the mainland of Belize, at $16^{\circ} 50^{\prime} \mathrm{N}, 88^{\circ} 06^{\prime} \mathrm{W}$ (Feller, 2002; McKee et al., 2002; Wooller et al., 2004a) (Figure 1). The two islands combined measure approximately $1.4 \mathrm{~km}$ long and $1.1 \mathrm{~km}$ wide (Woodroffe, 1995a) with an area of $\sim 92 \mathrm{ha}$ (Koltes et al., 1998). There are currently three species of mangrove trees present on Twin Cays: Rhizophora mangle L. (red mangrove), Avicennia germinans [L.] Stearn. (black mangrove) and Laguncularia racemosa [L.] Gaertn. f. (white mangrove) (Koltes et al., 1998; McKee et al., 2002). R. mangle is the dominant species on the island today (Koltes et al., 1998; Feller, 2002; Wooller et al., 2004a). This plant is present in a variety of heights ranging from dwarf $(<1.5 \mathrm{~m}$ high) to tall (>1.5 m high) growth forms (Feller, 1995; Woodroffe, 1995a; Koltes et al., 1998; McKee et al., 2002; Lovelock et al., 2006). The dwarf and tall forms are the same species, but the dwarf form is primarily phosphorus-limited and the tall form is primarily nitrogen-limited (Feller, 1995; Woodroffe, 1995a; Cameron and Palmer, 1995; Koltes et al., 1998; McKee et al., 2002; Lovelock et al., 2006). Trees of intermediate height ( $\sim 2-4 \mathrm{~m}$ tall) are limited by both nitrogen and phosphorus (Feller, 1995; McKee et al., 2002). This distribution in growth forms is apparent on many coastal islands in Belize (Woodroffe, 1995a). 


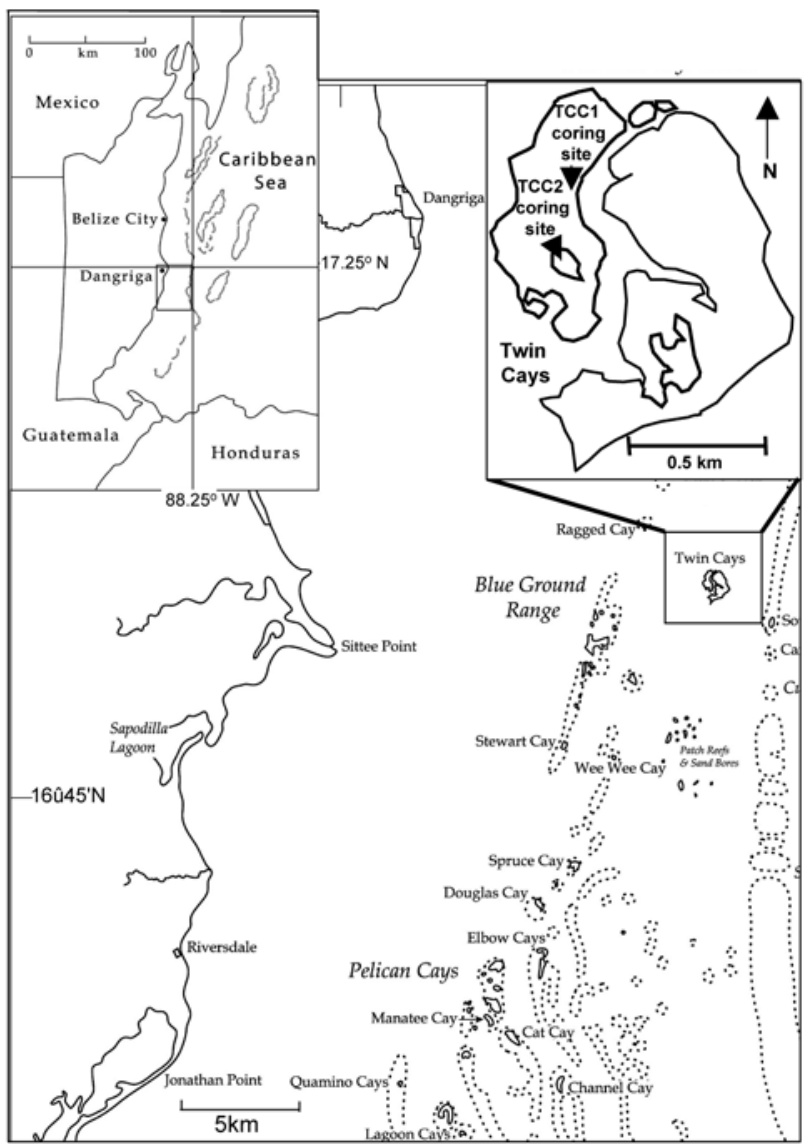

Figure 1 Location of core TCC2 (and TCC1) from Twin Cays, Belize (large-scale map adapted from Smithsonian Caribbean Coral Reef Ecosystems map)

Dwarf R. mangle are generally found near the island's interior, in ponds and basins partially closed off from tidal input (Woodroffe, 1995a). The tall form (usually 5-6 m tall on Twin Cays) generally surrounds the edge of the island and the banks of the channel separating the two islands, growing in areas more frequently inundated with seawater (Garcia and Holtermann, 1998; Koltes et al., 1998; McKee et al., 2002; Lovelock et al., 2006). Tall and dwarf growth forms of $R$. mangle have indistinguishable pollen but can possess different stable carbon and nitrogen isotopic sigantures $\left(\delta^{13} \mathrm{C}\right.$ and $\delta^{15} \mathrm{~N}$, respectively) (Wooller et al., 2003b, 2004a). Although decomposition of $R$. mangle leaves alters the original isotopic signatures, leaves from tall $R$. mangle trees generally exhibit $\delta^{13} \mathrm{C}$ values less than $-27 \%$, while $\delta^{13} \mathrm{C}$ of dwarf trees ranges from $-24 \%$ to $-26 \%$. The $\delta^{15} \mathrm{~N}$ values of tall trees generally range from $-2.8 \%$ to $+3.2 \%$, whereas dwarf trees are characterized by $\delta^{15} \mathrm{~N}$ values of $<-3 \%$ (Wooller et al., 2003b). These isotopic signatures are altered very little through the process of leaf senescence (Wooller et al., 2003b).

$A$. germinans are usually found inland of tall $R$. mangle and in regions less frequently inundated with seawater (Wooller et al., 2003b). Of the species found on Twin Cays, A. germinans is tolerant of high salt concentrations and survives in areas ranging from 38-65 parts per thousand (ppt) (Woodroffe, 1995a; Garcia and Holtermann, 1998; McKee and Faulkner, 2000b; Sobrado and Ewe, 2006). In addition to these four tree species, herbs, grasses and ferns are also present (Woodroffe, 1995a). Unvegetated flats, which are dry or shallow at low tide, characterize some areas in the interior of Twin Cays, and many are surrounded by dwarf $R$. mangle (Koltes et al., 1998; Woodroffe, 1995a).

A peat core, TCC2, was taken from an area in the interior of the west island of Twin Cays, where standing water and dwarf
R. mangle were present (Figure 1). A previous core, TCC1, has a basal age of $\sim 8300$ cal. yr BP and shows significant palaeoecological changes, including a period dominated by Myrsine sp. pollen (Wooller et al., 2004a). By developing a palaeoenvironmental reconstruction for Twin Cays, we aim to provide an improved assessment of local habitat variability in mangrove ecosystems during the Holocene.

\section{Methods}

\section{Field work}

A $780 \mathrm{~cm}$ core $(\mathrm{TCC} 2)$ of continuous peat was taken from the west island of Twin Cays, Belize (Figure 1) following the protocol described by Wooller et al. (2004a) using a Russian peat corer. Most of TCC2 $(0-715 \mathrm{~cm})$ is composed of mangrove peat, which contains $R$. mangle leaf fragments, roots and organic material. The bottom $65 \mathrm{~cm}(715-780 \mathrm{~cm})$ is a grey mud lacking macrofossils. The cores are currently stored $\left(\sim 4^{\circ} \mathrm{C}\right)$ at the Water and Environmental Research Center (WERC) at the University of Alaska Fairbanks.

\section{Radiocarbon dating, peat accumulation and penetrometer analysis}

R. mangle leaf fragments were picked from TCC2 in order to obtain seven accelerator mass spectrometry (AMS) radiocarbon dates. Once separated from the mangrove peat, the leaf fragments were washed with deionized water. Leaf fragments were sparse at $45 \mathrm{~cm}$ depth, so $1 \mathrm{~cm}^{3}$ of bulk peat was dated instead. The samples were freeze dried and stored in glass vials. The glass vials had previously been heated to $300^{\circ} \mathrm{C}$ in a muffle furnace to remove any organic contaminants. A sample from the outer layer of wood from a large ( $\sim 75 \mathrm{~cm}$ diameter) stump of a dead $A$. germinans that was present at the coring site was also sent for AMS dating. The samples were sent to the National Ocean Sciences Accelerator Mass Spectrometry Facility at Woods Hole Oceanographic Institution in Massachusetts for ${ }^{14} \mathrm{C}$ AMS dating. Radiocarbon dates were converted to cal. yr BP using Calib 5.0.2. (Stuiver et al., 1998) (http://calib.qub.ac.uk/calib/, last accessed 13 September 2007). Peat accumulation rates $(\mathrm{cm} / \mathrm{yr})$ were calculated for each of the core sections between radiocarbon dates, assuming constant accumulation between dated horizons.

The relative hardness of the TCC2 peat was assessed with a hand-held penetrometer (ELE International pocket penetrometer 29-3729 with adapter foot). The penetrometer was fitted with the $2 \mathrm{~cm}$ diameter flat foot, which is used for relatively soft material such as peat. While the peat core was held in its plastic core liner, the penetrometer was pushed into the peat at $3 \mathrm{~cm}$ intervals until the core surface was level with the top of the penetrometer foot. The reading of the gauge was then recorded. Two measurements were taken side by side at each depth, and the mean of the two measurements was calculated. A five point, weighted, running mean was calculated from these data.

\section{Pollen analyses}

Palynological processing and identification methods for TCC2 replicate methods for TCC1 (Wooller et al., 2004a). Approximately $1 \mathrm{~cm}^{3}(\sim 1 \mathrm{~g}$ to $2 \mathrm{~g}$ ) samples were taken at $10 \mathrm{~cm}$ intervals between $0 \mathrm{~cm}$ and $780 \mathrm{~cm}$. A tablet of exotic Lycopodium spores was added to each sample prior to acetolysis in order to determine the pollen concentration (grains $/ \mathrm{cm}^{3}$ ). Clay-sized particles were removed from the basal silt samples $(710-780 \mathrm{~cm})$ with a $7-10 \mu \mathrm{m}$ Nitex cloth sieve. The samples were mounted in glycerin jelly.

Whenever possible, a minimum of 300 grains were counted and identified for each sample. However, this was not always possible owing to low pollen concentrations. In such cases, a minimum of 


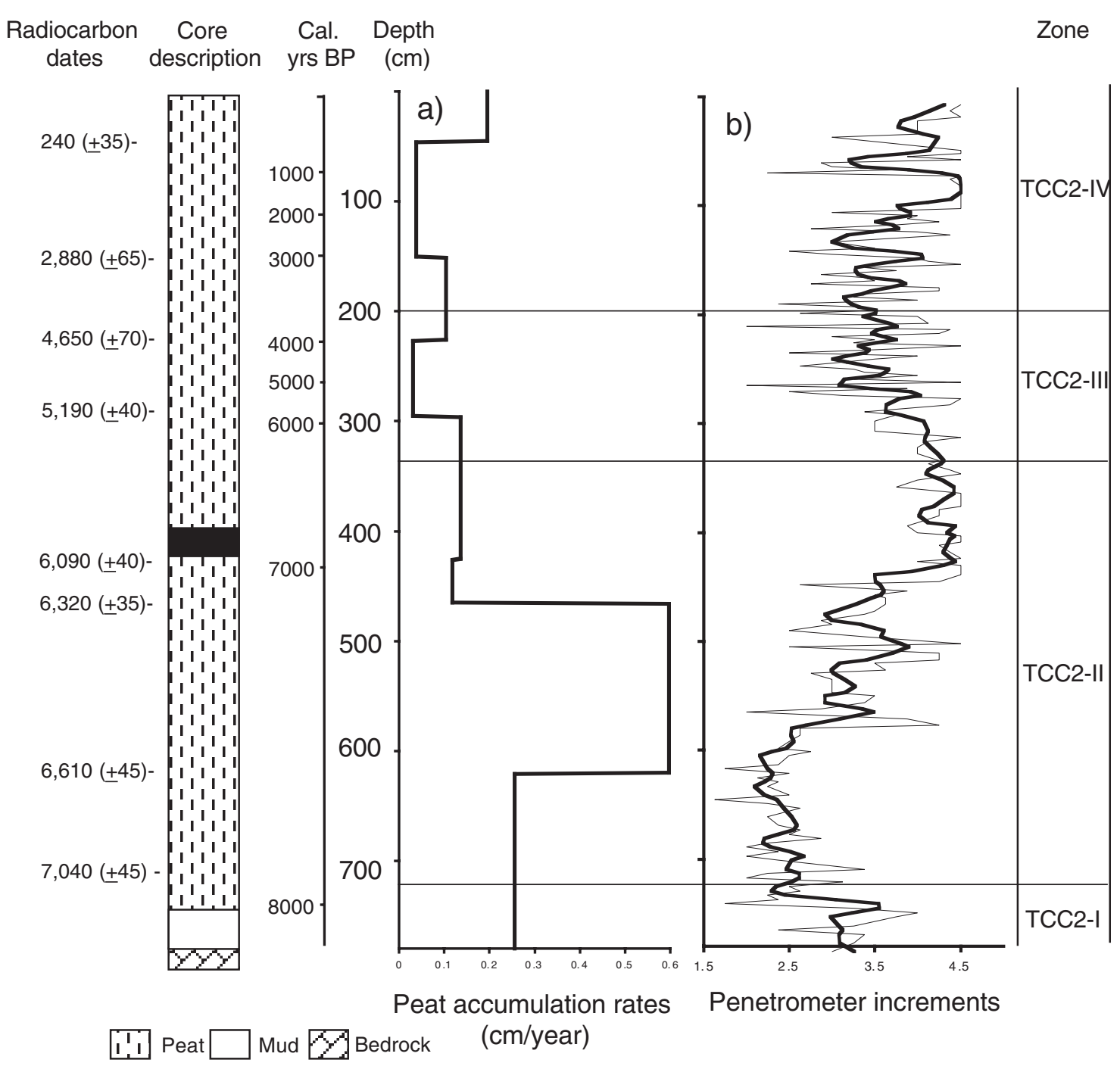

Observed as harder during coring

Figure 2 (a) Peat-accumulation rates between radiocarbon dates and (b) relative hardness and softness of peat (penetrometer increments) from TCC2

100 grains were identified and counted. Relative abundances are expressed as a percentage of the pollen sum. The pollen sum did not include foraminifera test linings, diatoms and fungal spores, which are recorded as the total number observed. Unidentified taxa represent a maximum $3 \%$ of the pollen sum. The pollen diagram was generated using TILIA (Grimm, 1987) and was zoned using CONISS in this program. All of the data from core TCC2 are reported relative to the pollen zones (see Figure 3).

\section{Carbon, nitrogen and oxygen stable isotope analyses of leaf fragments}

Mangrove leaf fragments were collected at $5 \mathrm{~cm}$ intervals throughout most of TCC2 $(0-605 \mathrm{~cm})$. The number and approximate proportions (length and width in $\mathrm{mm}$ ) of fragments from each sample were recorded to give an approximation of leaf-fragment abundance (leaf-fragment area, $\mathrm{cm}^{3}$ ) present at each sample depth (Wooller et al., 2004a). Since the fragments were sparse below $\sim 580 \mathrm{~cm}$, the sampling frequency decreased. From 605-730 cm, samples were taken at $10 \mathrm{~cm}$ intervals. There were no leaves below $730 \mathrm{~cm}$. Leaf fragments were rinsed with deionized water and freeze-dried prior to isotopic analysis.
In addition to the stable isotopes processed on $R$. mangle leaf fragments, five bulk (Total Organic Matter) sediment samples from the base of TCC2 were analysed. Bulk sediment samples taken from 710, 720, 740, 750 and $760 \mathrm{~cm}$ were acid-fumed to remove carbonate and freeze dried. Once dry, $0.30-0.50 \mathrm{mg}$ of each sample was weighed and placed in a $3.75 \mathrm{~mm}$ tin cup and crimped shut.

Acetanilide $\left(\mathrm{C}_{8} \mathrm{H}_{9} \mathrm{NO}\right)$ was used as a standard to determine the analytical precision for $\delta^{13} \mathrm{C}(0.2 \%), \delta^{15} \mathrm{~N}(0.3 \%), \% \mathrm{C}(6 \%)$ and $\% \mathrm{~N}(1 \%)$. An Elemental Analyser (EA) fitted to a stable-isotope ratio mass spectrometer (IRMS) (Ce Instruments, NA 2500 Series EA attached to a Finnigan MAT, Delta ${ }^{\text {plus }} \mathrm{XL}$ ) was used to produce $\delta^{13} \mathrm{C}$ and $\delta^{15} \mathrm{~N}$ values. Stable-isotope ratios $(\mathrm{C}$ and $\mathrm{N})$ are reported relative to Vienna Pee Dee Belemnite (VPDB) and air using standard delta notation. A five-point weighted running mean was calculated for the isotope data.

The $\delta^{18} \mathrm{O}$ of leaf fragments from TCC2 was analysed using the protocol and instrumentation described by Wooller et al. (2004b). The data are expressed relative to Vienna Standard Mean Ocean Water (VSMOW). Benzoic acid $\left(\mathrm{C}_{7} \mathrm{H}_{6} \mathrm{O}_{2}\right)$ was used to determine analytical precisions associated with $\delta^{18} \mathrm{O}$ and $\% \mathrm{O}$ analysis for each run, which were $0.4 \%$ and $2 \%$, respectively. 
Table 1 List of AMS radiocarbon dates (analysed at National Ocean Sciences Accelerator Mass Spectrometry Facility, NOSAMS) for core TCC2 from Twin Cays Belize using handpicked fragments of mangrove leaves (LF) or whole wood from a dead black mangrove (BMW)

\begin{tabular}{|c|c|c|c|c|c|c|}
\hline $\begin{array}{l}\text { NOSAMS } \\
\text { accession number }\end{array}$ & $\begin{array}{l}\text { Material } \\
\text { dated }\end{array}$ & $\begin{array}{l}\text { Depth } \\
(\mathrm{cm})\end{array}$ & $\begin{array}{l}{ }^{14} \mathrm{C} \text { yr } \\
\mathrm{BP}\end{array}$ & $\begin{array}{l}\text { Age } \\
\text { error }\end{array}$ & $\begin{array}{l}\text { Calibrated } \\
\text { age yr BP }\end{array}$ & $\begin{array}{c}\text { Calibrated } \\
\text { age range yr BP (1 sigma) }\end{array}$ \\
\hline OS-57502 & BMW & n.a. & 205 & 30 & 168 & $150-186$ \\
\hline OS-42359 & Peat & 45 & 240 & 35 & 230 & $151-312$ \\
\hline OS-54559 & LF & 150 & 2880 & 65 & 3014 & 2889-3139 \\
\hline OS-54558 & $\mathrm{LF}$ & 226 & 4650 & 70 & 3744 & $3644-3845$ \\
\hline OS-40701 & $\mathrm{LF}$ & 295 & 5190 & 40 & 5950 & $5911-5988$ \\
\hline OS-40699 & $\mathrm{LF}$ & 465 & 6320 & 35 & 7240 & $7163-7306$ \\
\hline OS-40698 & $\mathrm{LF}$ & 620 & 6610 & 45 & 7500 & $7434-7561$ \\
\hline OS-40697 & LF & 712 & 7040 & 45 & 7860 & $7792-7932$ \\
\hline
\end{tabular}

n.a., not applicable.
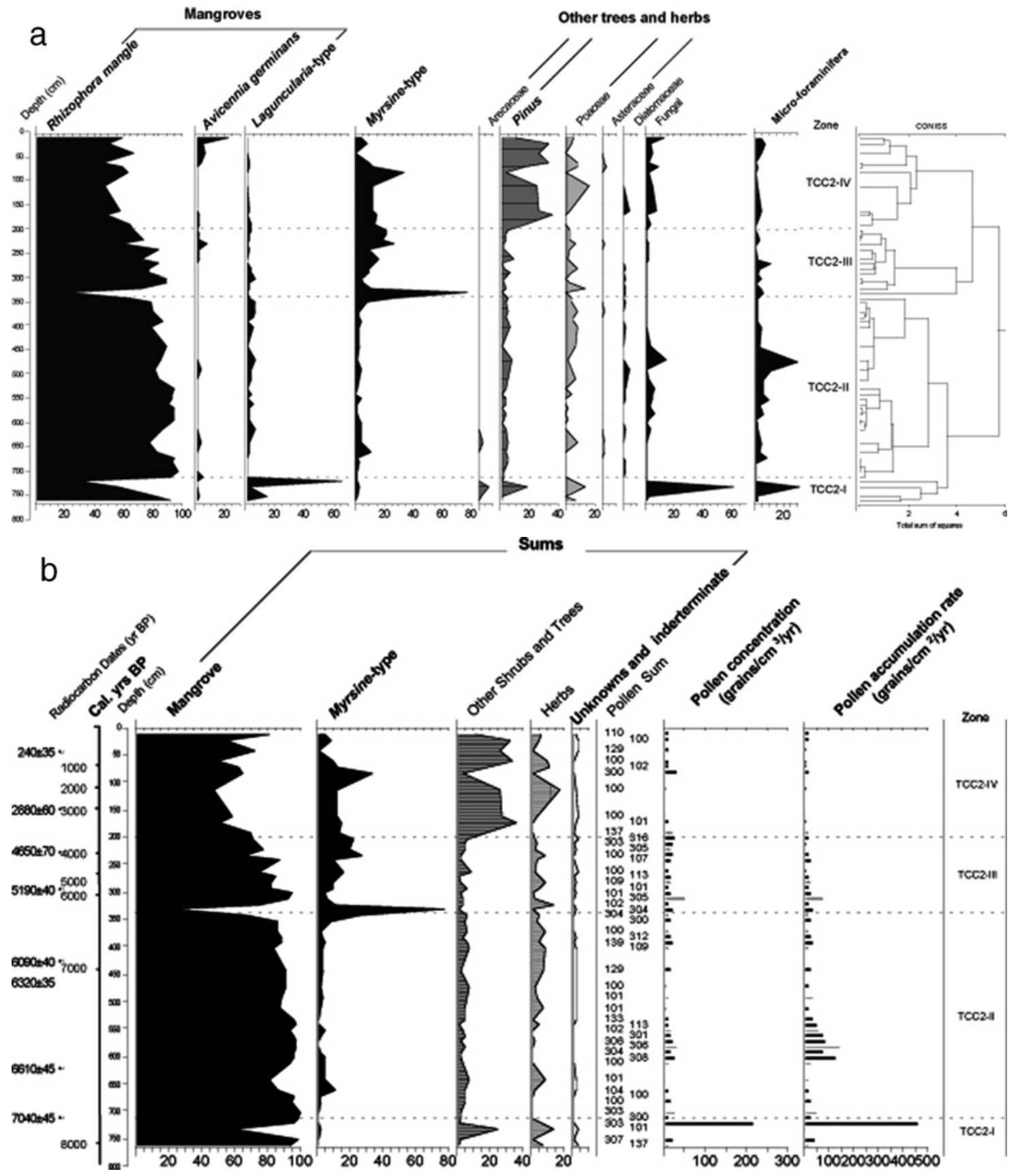

Figure 3 (a) Summary pollen diagram showing vegetation groups and pollen concentrations of the TCC2 core from Twin Cays, Belize. (b) Percentage pollen diagram of the most frequent pollen and spore taxa of the TCC2 core 


\section{Results}

\section{Core description and radiocarbon dates for core TCC2}

TCC2 was almost entirely composed of peat (Figure 2), with the exception of a small section $(\sim 780-710 \mathrm{~cm})$ composed of a fine grey mud that was harder than the peat (Figure 2b). During coring, a relatively hard layer of peat was encountered at $\sim 400$ $\mathrm{cm}$ overlying a softer layer of peat. These field observations are confirmed by the penetrometer data (Figure 2b), which show the peat below $\sim 450 \mathrm{~cm}$ to be relatively soft compared with the peat between $\sim 450 \mathrm{~cm}$ and $\sim 320 \mathrm{~cm}$. Another hard layer is evident at $\sim 100 \mathrm{~cm}$. The transition from relatively soft peat to harder peat at $\sim 450 \mathrm{~cm}$ correlates with a marked change in peat accumulation rates at site TCC2 (Figure 2). Below $\sim 460$ $\mathrm{cm}$ the peat accumulation rate ranged from $\sim 0.3$ to $0.6 \mathrm{~cm} / \mathrm{yr}$. Above $\sim 460 \mathrm{~cm}$ the peat accumulation rate is consistently $<\sim 0.3 \mathrm{~cm} / \mathrm{yr}$.

Eight radiocarbon dates were obtained from TCC2 (Table 1) at $45,150,226,295,425,465,620$ and $712 \mathrm{~cm}$. The radiocarbon dates presented herein have been converted to cal. yr BP (Table 1), and interpolation between these dates assumes constant accumulation rates between radiocarbon dates. Interpolated dates have been calculated for the boundaries between pollen zones at 200 , 345 and $720 \mathrm{~cm}$. An additional radiocarbon date of $168 \mathrm{cal}$. yr BP was obtained from the outer layer of a dead A. germinans mangrove stump at the site (Table 1).

The basal age of TCC2 is $\sim 8100$ cal. yr BP (extrapolated). The peat between $780 \mathrm{~cm}$ and $720 \mathrm{~cm}$ (pollen zone TCC2-I) accumulated between $\sim 8100$ and $\sim 7900$ cal. yr BP (Figure 2a). Peat between $720 \mathrm{~cm}$ and $345 \mathrm{~cm}$ (pollen zone TCC2-II) accumulated between $\sim 7900$ and $\sim 6300$ cal. yr BP, and peat in pollen zone TCC2-III $(345 \mathrm{~cm}$ to $200 \mathrm{~cm})$ accumulated between $\sim 6300$ and $\sim 3500$ cal. yr BP. The peat from $200 \mathrm{~cm}$ to the surface (pollen zone TCC2-IV) accumulated over $\sim 3500$ cal. years.

\section{Description of the pollen diagram from core TCC2}

Throughout most of TCC2, R. mangle pollen dominates the assemblages (Figure 3a, b). This is partially due to the fact that $R$. mangle produces greater amounts of pollen compared with A. germinans and L. racemosa (Behling et al., 2001). Within pollen zone TCC2-I, pollen concentrations and accumulation rates reach peak values (Figure $3 \mathrm{~b}$ ) and remain relatively high between 600 and $550 \mathrm{~cm}$, the interval with the highest peat accumulation rates (Figure 2). Pollen concentrations and accumulation rates are relatively uniform during pollen zone TCC2-III, but decrease markedly at the start of pollen zone TCC2-IV.

\section{Pollen zone TCC2-I}

The period represented by pollen zone TCC2-I is characterized by high amounts of $R$. mangle (56-98\%) (Figure 3a). At $\sim 750 \mathrm{~cm}$ there is a marked increase in other trees and shrubs (including Pinus). This is followed by a marked increase in L. racemosa-type pollen (up to $70 \%$ ).

\section{Pollen zone TCC2-II}

Pollen zone TCC2-II is characterized by high percentages of mangrove pollen $(\sim 80-100 \%)$ (Figure $3 b)$, which is dominated by $R$. mangle. Relatively low $(<20 \%)$ percentages of pollen from other trees and shrubs, including Myrsine-type and Pinus, are also evident throughout the zone. The distinguishing feature of this zone is the marked increase in the number of micro-foraminifera (Figure $3 \mathrm{~b}$ ) and fungal spores (Figure $3 \mathrm{a}$ ) at $\sim 450 \mathrm{~cm}$, preceded by an increase in the abundance of $A$. germinans pollen at $\sim 500 \mathrm{~cm}$. The zone ends with a marked decrease in $R$. mangle pollen and an increase in Myrsine-type pollen.

\section{Pollen zone TCC2-III}

The base of zone TCC2-III is distinguished by a spike $(>70 \%)$ in the abundance of Myrsine-type pollen. Above $\sim 330 \mathrm{~cm}$ the percentage

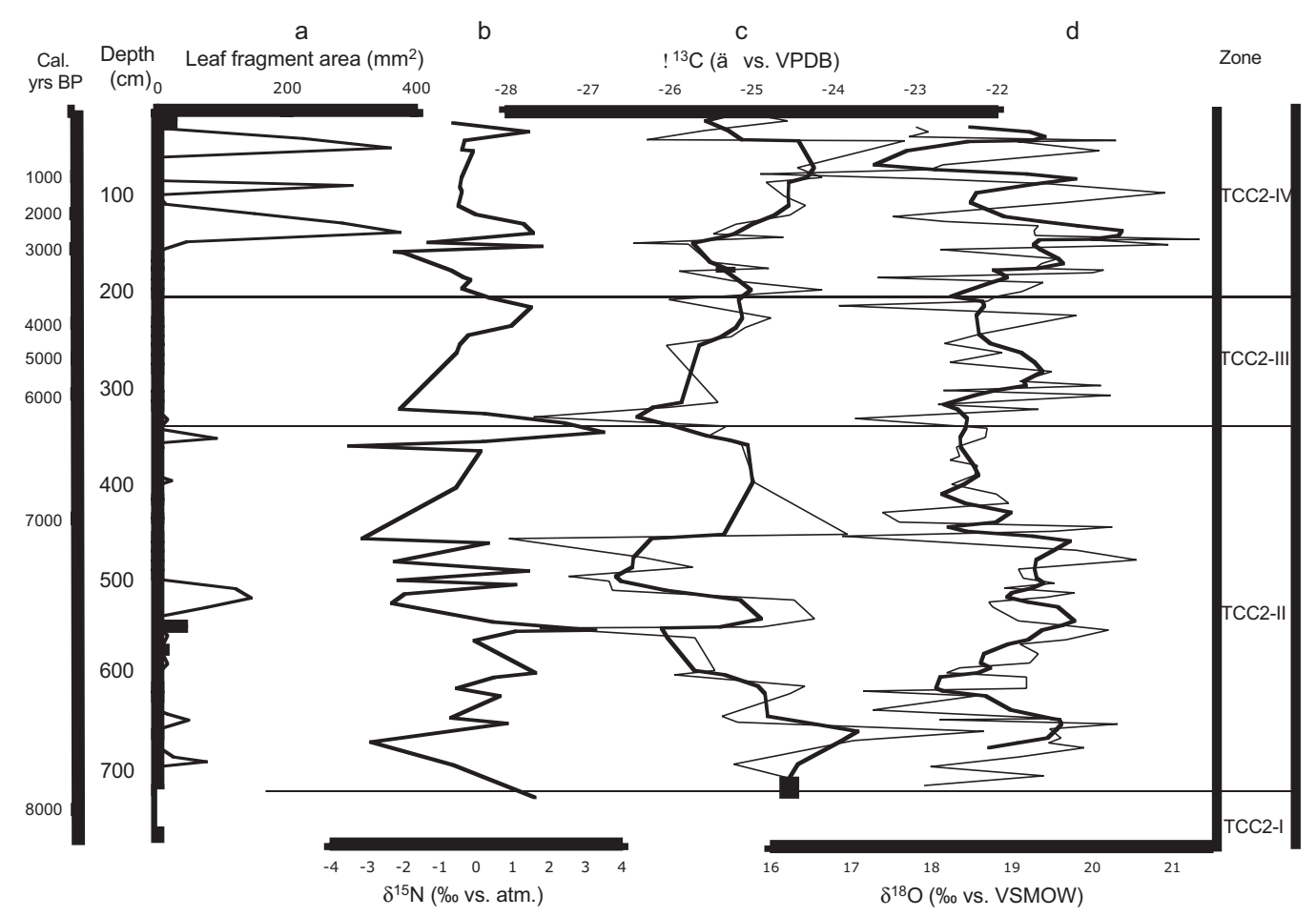

Figure 4 (a) Estimate of leaf-fragment area, (b) the stable nitrogen-, (c) carbon- and (d) oxygen-isotope composition of leaf fragments from core TCC2 
of Myrsine-type pollen generally increases from $\sim 5 \%$ to $\sim 30 \%$ at the end of the zone. Large amounts of $R$. mangle pollen (22-89\%) are present throughout. This zone contains low to moderate amounts of $A$. germinans (up to $7 \%$ ), L. racemosa (up to $5 \%$ ) and grass (up to $13 \%$ ) pollen. Fungal spores are rare, and the number of microforaminifera test linings varies from 1 to 15 .

\section{Pollen zone TCC2-IV}

Pollen assemblages between $200 \mathrm{~cm}$ and $0 \mathrm{~cm}$ contain high percentages of $R$. mangle pollen (41-75\%) and moderate amounts of forest taxa (5-32\% Pinus). Minor pollen types include Myrsine-type $(0-41 \%)$, A. germinans $(0-12 \%)$, L. racemosa $(0-2 \%)$, Poaceae $(0-16 \%)$ and Asteraceae $(0-2 \%)$. Fungal spores and microforaminifera are present in low numbers throughout the zone.

\section{Leaf fragments from TCC2}

Although leaf fragments were not present in the mud samples examined from pollen zone TCC2-I, leaf fragments are present in the overlying peat (Figure 4). Several peaks in leaf area are evident in pollen zone TCC2-II, with the two highest evident at $\sim 530 \mathrm{~cm}$ and $\sim 350 \mathrm{~cm}$. Very few fragments were found in pollen zone TCC2-III. The highest total leaf area was found in pollen zone TCC2-IV.

\section{Stable carbon, nitrogen and oxygen isotope data from the analysis of leaf fragments}

Although there is no significant correlation between the stable isotope data, it is noted that low $\delta^{13} \mathrm{C}$ are typically associated with relatively high values of $\delta^{18} \mathrm{O}$ (Figure 4). Bulk $\delta^{13} \mathrm{C}$ and $\delta^{15} \mathrm{~N}$ values from zone TCC2-I ranged from $-26.3 \%$ to $-26.8 \%$ and $6.2 \%$ to $7.7 \%$, respectively. The leaf fragments from pollen zone TCC2-II reveal decreasing values of $\delta^{15} \mathrm{~N}$, from $\sim 1.5 \%$ at the start of the zone to $\sim-3 \%$ at $\sim 670 \mathrm{~cm}$. Above $670 \mathrm{~cm}, \delta^{15} \mathrm{~N}$ increases to a peak value of $\sim 3 \%$ at $\sim 550 \mathrm{~cm}$. Between $\sim 550 \mathrm{~cm}$ and $\sim 450$ $\mathrm{cm} \delta^{15} \mathrm{~N}$ values range between $-3 \%$ and $1.5 \%$. From $\sim 450 \mathrm{~cm}$ to the end of the zone, the $\delta^{15} \mathrm{~N}$ values increase from $-3 \%$ to $3.5 \%$. $\delta^{13} \mathrm{C}$ values reveal an overall decrease from $-24 \%$, near the base of the zone, to a minimum value of $-28 \%$ at $\sim 450 \mathrm{~cm}$. Between $\sim 550 \mathrm{~cm}$ and $500 \mathrm{~cm}$ values increase to $\sim-24 \%$. At $\sim 450 \mathrm{~cm} \delta^{13} \mathrm{C}$ values increase abruptly to $\sim-21 \%$, followed by a slight decrease to $\sim-25 \%$ at the top of the zone. $\delta^{18} \mathrm{O}$ values peak twice during this zone, once near the base of the zone $(\sim 650 \mathrm{~cm})$ and again between $\sim 550$ and $450 \mathrm{~cm}$. A marked decrease in $\delta^{18} \mathrm{O}$ occurs at $\sim 450 \mathrm{~cm}$, with values as low as $17 \%$. $\delta^{18} \mathrm{O}$ values then remain relatively stable $(\sim 18 \%)$ for the duration of the zone.

A sharp decrease in $\delta^{15} \mathrm{~N}$ from $\sim 3 \%$ to $-2 \%$ occurs at the start of pollen zone TCC2-III, after which $\delta^{15} \mathrm{~N}$ values generally increase to $\sim 1 \%$ at the top of the zone. $\delta^{13} \mathrm{C}$ values also increase overall throughout the zone from a low of $\sim 28 \%$ at the base of the zone to $\sim 25 \%$ at the top. $\delta^{18} \mathrm{O}$ increases from a low value of $\sim 17 \%$ at the base of the zone to $20 \%$ at $\sim 300 \mathrm{~cm}$, after which values generally decrease to $\sim 17 \%$ at the top of the zone.

$\delta^{15} \mathrm{~N}$ values decrease from $\sim 2 \%$ at the base of pollen zone TCC2-IV to $-2 \%$ at $160 \mathrm{~cm}$, with two slight peaks (up to $2 \%$ ) at $\sim 130 \mathrm{~cm}$ and at $\sim 10 \mathrm{~cm} . \delta^{13} \mathrm{C}$ values decrease slightly from $-24 \%$ o at the base of the zone to $-26.5 \%$ at $\sim 150 \mathrm{~cm}$, then increase to $23 \%$ at $30 \mathrm{~cm}$. $\delta^{18} \mathrm{O}$ values increase from $\sim 17 \%$ at the base of the zone to a maximum value of $\sim 21 \%$, at $\sim 150 \mathrm{~cm}$. Two lesser peaks occur at $120 \mathrm{~cm}$ and $\sim 50 \mathrm{~cm}$, followed by an abrupt decrease in $\delta^{18} \mathrm{O}$ to a minimum value of $16 \%$ at $\sim 100 \mathrm{~cm}$.

\section{Discussion and interpretation}

\section{Zone TCC2-I (8100 to 7900 cal. yr BP)}

Mangroves established at the site of TCC2 on a mud-covered limestone platform $\sim 8100$ cal. yr BP, coincident with development of mangroves at other locations on the island (eg, Wooller et al., 2004a). The initial mangrove stand was composed of L. racemosa, $R$. mangle and A. germinans. Since both A. germinans and L. racemosa are relatively low pollen producers (Behling et al., 2001), the very presence of their pollen indicates that they probably comprised a substantial proportion of the local vegetation.

Since our chronology is primarily based on radiocarbon analyses of leaf fragments, we have avoided some of the problems associated with dating mangrove peat samples (see Gischler and Hudson, 2004; Gischler, 2006). For instance, when analyses are conducted on bulk peat the date of the sample can be complicated by the penetration of younger roots into older peat. We acknowledge that dating material, such as leaves, from mangrove peat does not avoid some of the variability associated with slight differences in substrate elevation between different mangrove habitats. However, these elevation differences are relatively small in Belize, even if peat is encountered from $A$. germinans, which usually grows at slightly higher elevations (see discussions in Blanchon and Shaw, 1995; Toscano and Macintyre, 2003; Gischler and Hudson, 2004; Blanchon, 2005; Gischler, 2006). Differences in elevation do not pose a problem, because the primary goal of our study is to date changes in the core, not to use the dates to estimate the relative height of sea level.

The relatively high bulk $\delta^{15} \mathrm{~N}$ values of the mud from the base of the core (older than 7900 cal. yr BP) suggest that this site may have received deposits of bird guano. High $\delta^{15} \mathrm{~N}$ values have previously been observed in all aspects (eg, peat and mangrove trees) of Man of War Cay, a mangrove island near Twin Cays (Wooller et al., 2003a). Man of War Cay hosts a large number of marine birds (eg, frigate birds) that contribute large amounts of nitrogenrich bird droppings to the sediment. A similar environment may have prevailed during the early formation of Twin Cays.

In Belize the highest diversities of foraminifera have been found in well-circulated areas of normal and constant marine salinities (Gischler et al., 2003). The duration and frequency of subaerial exposure have been shown to be the most important factors influencing the abundance foraminifera associated with some mangrove habitats (Woodroffe et al., 2005). Thus, multiple lines of evidence, including $\delta^{15} \mathrm{~N}$ values, mixed mangrove stands and relatively high number of micro-foraminifera, suggest that this site, currently located in the centre of the western island of Twin Cays, was a transitional mangrove habitat during zone TCC2-I. The presence of Arecaceae, the Palm family, can also be attributed to a transitional mangrove habitat (Torrescano and Islebe, 2006). A lithology of this type is consistent with the sequence that occurred during the flooding of the platform in Belize during the early part of the Holocene (Halley et al., 1997).

\section{Zone TCC2-II (7900 to 6300 cal. yr BP)}

The base of pollen zone TCC2-II, at $7900 \mathrm{cal}$. yr BP, is distinguished by a change in sediment composition from grey mud to the pure mangrove peat typical of the rest of the core. This transition coincides with the first appearance of mangrove leaf fragments. The entire zone, from the base to the top at $6300 \mathrm{cal}$. yr BP, is dominated by pollen of $R$. mangle, with minor contributions from other mangrove species.

Myrsine-type pollen is present in small amounts. Whereas plants that produce this pollen type are not known to be present on the island today, species of Myrsine are found on the mainland (Balick et al., 2001). Some producers of Myrsine-type pollen are documented disturbance indicators (Ardisia escallonioides and Myrsine coriacea) (Pascarella, 1998). High concentrations of Myrsine-type pollen are also recorded at intervals in core TCC1 (Wooller et al., 2004a). However, the relatively low concentrations present throughout zone TCC2-II are consistent with regional transport, possibly from the mainland. This is likely also the case for pollen of Pinus and Poaceae. 
A 'stepped' increase (Blanchon, 2005) in the rate of rise in sea level in the Caribbean is recorded between $\sim 8500 \mathrm{cal}$. yr BP and $\sim 7500$ cal. yr BP, although the temporal resolution of this event is relatively coarse. After 7700 cal. yr BP, the rate of rise in sea level apparently decreased from $\sim 5.2 \mathrm{~mm} / \mathrm{yr}$ to $\sim 1.5 \mathrm{~mm} / \mathrm{yr}$ (Toscano and Macintyre, 2003). Sea-level curves presented by Gischler and Hudson (2004) and Gischler (2006) indicate that the decrease in the rate of sea-level rise occurs after $\sim 7000 \mathrm{cal}$. yr BP. This decrease in the rate of sea-level rise correlates with a decrease in peataccumulation rates, which likely occurred as mangroves at the site adjusted to the decelerating rate of sea-level rise. Correlation between these events supports the interpretation that the change in peat accumulation rate resulted from sea-level changes, rather than a catastrophic die-off of mangroves, which can cause peat collapse (eg, Cahoon et al., 2003). Although the pollen data imply that species composition remained relatively constant during this time, peat accumulation rates, peat hardness and stable isotope data record some marked ecological changes. After 7200 cal. yr BP peat-accumulation rates decreased significantly.

Relatively sharp isotopic changes recorded at $\sim 7200$ cal. yr BP on Twin Cays imply that the $R$. mangle habitat became less regularly inundated with seawater. This is evident from the abrupt increase in $\delta^{13} \mathrm{C}$ and concurrent decrease in $\delta^{15} \mathrm{~N}$ to minimum $\left(<3 \%\right.$ ) values between 7200 and 6300 cal. yr BP. High $\delta^{13} \mathrm{C}$ and low $\delta^{15} \mathrm{~N}$ values are typical of dwarf $R$. mangle found in the interior of the modern island. Tidal delivery replenishes phosphorus in the sediment but toward the interior tidal influx is limited, creating less nutrient exchange (Feller, 1995). Today the majority (but not all) of the dwarf trees are found towards the interior areas of Twin Cays. Decreasing $\delta^{18} \mathrm{O}$ values support reconstruction of a site at TCC2 less inundated with seawater after $7200 \mathrm{cal}$. yr BP. Whereas the $\delta^{18} \mathrm{O}$ of lacustrine proxies are interpreted on the basis of evaporation to precipitation ratios (eg, Curtis et al., 1996, 1998), our data are more liable to be a reflection of changes in the proportions of precipitation versus seawater, because mangroves derive their water from varying proportions of these two end members (Ishshalomgordon et al., 1992). Although variations in the $\delta^{18} \mathrm{O}$ of plants can be challenging to interpret (McCarroll and Loader, 2004), decreasing $\delta^{18} \mathrm{O}$ values after $\sim 7200$ cal. yr BP in $\mathrm{TCC} 2$ are consistent with mangroves deriving a greater proportion of water from tropical precipitation, which is liable to have a more negative $\delta^{18} \mathrm{O}(\mathrm{eg},<-4 \%$ ) relative to ocean water (standard mean ocean water $=0 \%$ ) (eg, Benway and Mix, 2004). Detailed studies of the controls of $\delta^{18} \mathrm{O}$ in modern mangrove habitats have shown that mangrove organic matter is likely a reliable record of the $\delta^{18} \mathrm{O}$ of source water and the proportion of seawater versus rainwater (Sternberg and Swart, 1987; Lin and Sternberg, 1993, 1994; Verheyden et al., 2004). Our own modern precipitation $\delta^{18} \mathrm{O}$ data (N. Monacci and M.J. Wooller, unpublished data, 2007) supports this finding. In addition, we have found that the difference $\left(\sim 26 \%\right.$ ) between the $\delta^{18} \mathrm{O}$ of modern mangrove leaves in Belize and the $\delta^{18} \mathrm{O}$ of water in the substrates of mangroves habitats is consistent with the fractionation associated with carbohydrate synthesis by plants (reviewed by McCarroll and Loader, 2004) and cellulose synthesis in $R$. mangle leaves (Ishshalomgordon et $a l ., 1992)$. We therefore consider that the most logical interpretation of the marked decrease in the $\delta^{18} \mathrm{O}$ at $\sim 7200 \mathrm{cal}$. yr BP is a decrease in the proportion of seawater inundating site TCC2. Although a similar shift could be produced by increasing the proportion of rainfall relative to seawater at the site, the former intepretation is more likely given the correlation between the timing of the $\delta^{18} \mathrm{O}$ decrease $(\sim 7200 \mathrm{cal}$. yr BP) with the documented decrease in the rate of sea-level rise (ie, Gischler, 2006).

Analyses of coral skeletons from the Belize reef complex have revealed seasonal variations in $\delta^{18} \mathrm{O}$ (Gischler and Oschmann, 2005). Although changes in water temperature were taken into account, Gischler and Oschmann (2005) partially attribute these alterations in the $\delta^{18} \mathrm{O}$ of the water surrounding the coral. They note that high temperatures coincide with high seasonal rainfall, lowering the $\delta^{18} \mathrm{O}$ in the coral. Corals from the Belize reef complex also show a marked decrease in $\delta^{18} \mathrm{O}$ (up to $\sim 2 \%$ ) after $\sim 6990$ yr BP (Gischler and Oschmann, 2005).

\section{Zone TCC2-III (6300 to 3500 cal. yr BP)}

The transition to pollen zone TCC2-III at $\sim 6300 \mathrm{cal}$. yr BP is associated with a series of habitat changes. At the base of the zone the abundance of Myrsine-type pollen peaks abruptly before declining to background levels. From 6300 to $3500 \mathrm{cal}$. yr BP the $\delta^{13} \mathrm{C}$ of the mangrove leaves decreased and the $\delta^{18} \mathrm{O}$ increased, implying greater inundation with ocean water. This interpretation is consistent with slight increase in the number of micro-foraminifera at $\sim 4700$ cal. yr BP and with evidence for a stepped increase in the rate of rise in sea level at this time (Blanchon, 2005). A major flooding event between $\sim 6400$ and $\sim 5500$ cal. yr BP at Cobweb Swamp on the Belize mainland was associated with rising sea level (Jacob and Hallmark, 1996), and a high stand in sea level occurred along the eastern Brazilian coast between 5800 and 5000 cal. yr BP (Angulo et al., 2006). Flooding of the Rio Honde and increases in mangrove habitat area in southeastern Mexico after $\sim 4600$ cal. yr BP have also been attributed to a rise in sea level (Torrescano and Islebe, 2006).

After $\sim 5800$ cal. yr BP the percentage of the Myrsine-type pollen in TCC2 again increases. A secondary peak at $\sim 3600$ cal. yr BP is coeval with very high concentrations of Myrsine-type pollen in core TCC1 (Wooller et al., 2004a). Although percentages of Myrsine-type pollen remain relatively high between 4500 and 3500 cal. yr BP at the site of TCC2, we do not see the very high concentrations evident between 4280 and $4040 \mathrm{cal}$. yr BP in TCC1. It seems likely that a plant producing Myrsine-type pollen was local to Twin Cays during this time period, when the island supported a heterogeneous patchwork of habitats. The $\delta^{13} \mathrm{C}$ and $\delta^{15} \mathrm{~N}$ data imply that the $R$. mangle at the site of core TCC 2 were of a transitional type, while the pollen data indicate that they were interspersed with A. germinans and L. racemosa.

\section{Zone TCC2-IV (3500 cal. yr BP to present)}

The base of pollen zone TCC2-IV records a significant increase in the percentage of pollen from Pinus and Poaceae. The low pollen concentrations imply that these types, which are known to be transported over long distances, are most likely from the mainland. Although the increase in pine and grass pollen could be associated with a change in the prevailing wind direction, the abundance of Pinus on Twin Cays is a likely a direct result of increased amounts of Pinus on mainland Belize. The $\sim 3500 \mathrm{cal}$. yr BP increase is coeval with an increase in Pinus pollen in core TCC1 (Wooller et al., 2004a) and at various sites on the mainland (Leyden, 1987; Islebe et al., 1996; Curtis et al., 1998; Wahl et al., 2006). Regional climatic changes (warmer and wetter) caused a change in mainland vegetation from savanna to forest $\sim 4000$ cal. yr BP (Markgraf, 1993; Leyden, 2002). Drier conditions followed (Curtis et al., 1996), and an interval of peak aridity 1300 and 1100 cal. yr BP has been related to the collapse of the Classic Maya civilization (Hodell et al., 1995). After 3500 cal. yr BP, the TCC2 site is dominated by $R$. mangle and, according to the $\delta^{13} \mathrm{C}$ and $\delta^{15} \mathrm{~N}$ data, these trees were of a transitional type. A marked increase in the $\delta^{18} \mathrm{O}$ to the maximum core values $\sim 2500 \mathrm{cal}$. yr BP is associated with a decrease in the $\delta^{13} \mathrm{C}$. These changes imply that the site was more frequently inundated with seawater, and the stand structure of $R$. mangle changed from transitional to tall. This hypothesis is supported by sea-level reconstructions that suggest that the rate of rise in sea level slowed (from $1.5 \mathrm{~mm} / \mathrm{yr}$ to $0.9 \mathrm{~mm} / \mathrm{yr}$ ) after 2000 cal. yr BP (Toscano and Macintyre, 2003). An 
increase in inundation by seawater may account for the rise in some lake levels on the Belize mainland after 3400 cal. yr BP through raising of phreatic aquifers (Alcalaherrera et al., 1994). A subsequent peak in the Myrsine-type pollen at $\sim 1000$ cal. yr BP on Twin Cays, which has previously been associated with a decrease in seawater inundation (Wooller et al., 2004a), is associated with a marked decrease in $\delta^{18} \mathrm{O}$, indicating that more pore water was derived from precipitation. This increase in Myrsine-type pollen is also associated with a relatively hard portion of the peat core and a subsequent increase in the percentage of $A$. germinans pollen, indicative of development of a mixed stand of $R$. mangle and $A$. germinans. Although this is not consistent with the vegetation of the modern site (ie, an interior pond dominated by R. mangle), inspection of the pond revealed a number of very large (up to $\sim 1$ m diameter) submerged $A$. germinans stumps, with the outer portion of one of the larger stumps producing a radiocarbon date of 168 cal. yr BP (Table 1). Evidence for maximum middle to late Holocene aridity on the mainland is derived from $\delta^{18} \mathrm{O}$ analyses of inorganic biological fractions (eg, ostracods and gastropods) in lakes of Central and South America (eg, Hodell et al., 1991; Curtis et al., 1996, 1998; Whitmore et al., 1996). The isotopic and palynological changes we document at the site of TCC2 1000 cal. yr $\mathrm{BP}$ record a change in the mangrove ecosystems off of the coast of Belize, raising the possibility that changes in sea level may have played a key role in late-Holocene palaeoenvironmental changes of Central America.

Our data provide evidence of changes in the composition and physiology of mangrove habitats on Twin Cays throughout the middle to late Holocene. Two new proxies were included in our multiproxy analysis of mangrove peat cores: $\delta^{18} \mathrm{O}$ analyses of leaf fragments and penetrometer measurements of the relative hardness of the peat. As with the application of any novel proxies of past environments, there is the need for further investigations. For instance the $\delta^{18} \mathrm{O}$ data are generated from the analysis of total organic oxygen retained in the leaf fragments. We acknowledge that some of the variation in our data may represent diagenetic alteration of the organic composition of the leaves over time. Studies of the stable-isotope composition of organic material preserved in deposits sometimes resort to the analysis of recalcitrant single compounds or groups of compounds (eg, Ficken et al., 2000) to reduce the possible noise associated with diagenesis. In terms of the $\delta^{13} \mathrm{C}$ and $\delta^{15} \mathrm{~N}$ analyses of leaf fragments, we set up a series of taphonomic experiments to assess the degree to which the isotopic signatures are likely to be altered over time (Wooller et al., 2003b). These experiments showed that despite various taphonomic processes that take place prior to a mangrove leaf being preserved in peat, including leaf senescence, the $\delta^{13} \mathrm{C}$ and $\delta^{15} \mathrm{~N}$ could still distinguish leaves from tall versus dwarf $R$. mangle. The analyses were performed only after it had been established that variation was preserved in bulk isotope measurements of leaf fragments from peat cores (Wooller et al., 2003b). We provide evidence that the bulk $\delta^{18} \mathrm{O}$ of leaf fragments in peat cores varies over time, sometimes in accordance with other proxies. We now see merit in performing a study of the $\delta^{18} \mathrm{O}$ of leaf fragments during taphonomic processes (ie, senescence), similar to that of Wooller et al. (2003b).

We also see merit in further assessments of the physical characteristics of peat cores. The penetrometer data has illustrated marked shifts between hard and soft peat that cannot be ascribed to burial and compaction (ie, softer peat at the bottom of the core and harder peat at the surface). Despite the fact that some sections of the TCC2 penetrometer data are exceedingly variable, some portions of the core are consistently harder. A similar trend is also evident in the core TCC1 from Twin Cays. Thus, penetrometer analyses are a potential correlation tool.

Rates of rise in sea level are known to have varied during the Holocene, with an overall deceleration towards the present day.
During the early Holocene, when the rate of rise in sea level was still relatively high $(\sim 5 \mathrm{~mm} / \mathrm{yr})$, peat-accumulation rates were highest. Calculations of peat-accumulation rates for the deeper part of our core TCC2 may even be considerable underestimations, since the base of the core may have undergone the most compaction.

We find both similarities and dissimilarities between the two cores from Twin Cays (TCC1, Wooller et al., 2004a; and TCC2, this study). Many features of the data from site TCC2 are consistent with the previous findings from site $\mathrm{TCC} 1$. We have noted very similar trends in the penetrometer data from both cores (TCC2 Figure $2 \mathrm{~b}$ and TCC1 M.J. Wooller, unpublished data, 2007). We also note marked decreases in sedimentation rate at $\sim 7000$ cal. yr BP in both cores. In terms of the pollen, we note that both sites were covered by $R$. mangle throughout the majority of the Holocene. High percentages of $R$. mangle dominate the pollen assemblages from both $\mathrm{TCC} 1$ and $\mathrm{TCC} 2$ during the period from $\sim 8000$ cal. yr BP to $\sim 5000$ cal. yr BP. Although both sites show a marked single peak in the percentage of Myrsine-type pollen during this period, these peaks do not correlate. However, a marked increase in the percentage of Myrsine-type pollen from $\sim 4300 \mathrm{cal}$. yr BP until 3800 cal. yr BP in core TCC2 correlates with the previously published (Wooller et al., 2004b) high concentrations of this pollen type documented in core TCC1. Since the percentages and concentrations of this pollen type in core TCC2 do not approach the high levels previously shown in core TCC1 during this time period, it seems that this feature of the pollen assemblages was locally restricted to site TCC1 at Twin Cays. This interval is also represented by a notable absence or reduction in the leaf fragment area and an increase in the percentage of $\mathrm{A}$. germinans pollen in both cores. In addition, both cores show a marked increase in the percentage of pollen from Pinus and other shrubs and trees after $\sim 4000$ cal. yr BP, which has previously been interpreted as changes in the proportion of pollen derived from the mainland (Wooller et al., 2004b). Both pollen diagrams show a decrease followed by an increase in the percentage of Pinus pollen between 2000 and 1000 cal. yr BP. Broad changes (ie, weighted running means) in the stable isotopic trends (TCC2 Figure 4 and TCC1 based on published isotope data in Wooller et al., 2004b) also show similarities, most notably a marked decrease in $\delta^{13} \mathrm{C}$ from $\sim 7600$ to $\sim 7000 \mathrm{cal}$. yr BP. Further synthesis of the patterns will be possible once similar multiproxy records have been established from other sites in Belize (eg, Drowned Cays, N. Monacci and M.J. Wooller, unpublished data, 2007).

\section{Conclusions}

Our data have implications for predicting how mangrove ecosystems may respond to future changes in sea level. A range of scenarios and rates of rise in sea level are predicted for the next $\sim 100$ years (AMAP et al., 2004). Mangroves at Twin Cays were able to maintain a mangrove habitat despite changing Holocene sea levels; these data suggest that frequent inundations with seawater stimulate higher rates of peat accumulation in mangrove habitats. This likely 'releases' mangroves from the nutrient limitation that dwarf mangroves experience in the interior of mangrove cays in Belize (Feller, 1995; Lovelock et al., 2006). However, some sealevel scenarios predict higher rates of rise in the future than those evident in the Caribbean during the Holocene (ie, $>5 \mathrm{~mm} / \mathrm{yr}$ ) (AMAP et al., 2004). It is not possible to say at what point mangroves on cays such as Twin Cays may be unable to maintain a sufficient peat-accumulation rate to keep up with these higher rates of rise in sea level. It seems that past decreases in the rate of rise in sea level, or possible decreases in sea level, coincide with some of the most marked Holocene changes in mangrove habitats 
located on Twin Cays. These changes include a decrease in peat accumulation, an increase in peat hardness and, in some instances, species-composition changes and changes in the stand structure of the dominant modern mangrove ( $R$. mangle). The ecological 'options' for mangrove ecosystems along barrier islands, on atolls and on cays, are more limited compared with mangroves on the mainland, which have the additional option of migrating inland in response to marine transgressions. During the earlier part of the Holocene, mangroves at site TCC2 were able to keep pace with a relatively rapid rise in sea level. Our data also imply that the mangroves were able to take advantage of varying proportions of precipitation versus seawater during the Holocene, which likely came about as the rate of sea-level rise changed.

\section{Acknowledgements}

We thank Dr Myrna Jacobson, Dr Bruce Finney, Dr Jennifer Eigenbrode and Ms Natalie Monacci for valuable discussions related to this work. We also thank the Smithsonian Marine Station at Carrie Bow Cay (most notably Dan Miller and Claudette DeCourley) for logistical support during our fieldwork. This research was supported by funding from NSF grants awarded to Wooller, Finney (NSF DEB0708177) and Fogel (NSF DEB0708177 and NSF Biocomplexity 99-81535). We thank two anonymous reviewers and H.E. Wright for constructive comments that improved our paper.

\section{References}

Alcalaherrera, J.A., Jacob, J.S., Castillo, M.L.M. and Neck, R.W. 1994: Holocene paleosalinity in a Maya wetland, Belize, inferred from the microfaunal assemblage. Quaternary Research 41, 121-30.

Arctic Monitoring and Assessment Programme, Conservation of Arctic Flora and Fauna and International Arctic Science Committee 2004: Arctic impact assessment. Univeristy of Cambridge. Angulo, R.J., Lessa, G.C. and de Souza, M.C. 2006: A critical review of mid- to late-Holocene sea-level fluctuations on the eastern Brazilian coastline. Quaternary Science Reviews 25, 486-506.

Balick, M.J., Nee, M.H. and Atha, D.E. 2001: Checklist of the vascular plants of Belize: with common names and uses. Memoirs of the New York Botanical Garden.

Behling, H. and da Costa, M.L. 2001: Holocene vegetational and coastal environmental changes from the Lago Crispim record in northeastern Para State, eastern Amazonia. Review of Palaeobotany and Palynology 114, 145-55.

Behling, H., Cohen, M.C.L. and Lara, R.J. 2001: Studies on Holocene mangrove ecosystem dynamics of the Braganca Peninsula in north-eastern Para, Brazil. Palaeogeography Palaeoclimatology Palaeoecology 167, 225-42.

Benway, H.M. and Mix, A.C. 2004: Oxygen isotopes, upper-ocean salinity, and precipitation sources in the eastern tropical Pacific. Earth and Planetary Science Letters 224, 493-507.

Blanchon, P. 2005: Comments on 'Corrected western Atlantic sealevel curve for the last 11,000 years based on calibrated C-14 dates from Acropora palmata framework and intertidal mangrove peat' by Toscano and Macintyre. Coral Reefs 24, 183-86.

Blanchon, P. and Shaw, J. 1995: Reff drowning during the last deglaciation: evidence for catastrophic sea-level rise and ice-sheet collapse. Geology 23, 4-8.

Blasco, F. 1984: Mangrove evolution and palynology. In Snedaker, S.C. and Snedaker, J.G., editors, The mangrove ecosystem: research methods. United Nations Educational, Scientific and Cultural Organization, 36-49.

Bowen, G.J., Wassenaar, L.I. and Hobson, K.A. 2005: Global application of stable hydrogen and oxygen isotopes to wildlife forensics. Oecologia 143, 337-48.

Cahoon, D.R., Hensel, P., Rybczyk, J., McKee, K.L., Proffitt, C.E. and Perez, B.C. 2003: Mass tree mortality leads to mangrove peat collapse at Bay Islands, Honduras after Hurricane Mitch. Journal of Ecology 91, 1093-105.

Cameron, C.C. and Palmer, C.A. 1995: The mangrove peat of the Tobacco Range Islands, Belize Barrier Reef, central America. Atoll Research Bulletin 431, 1-32.

Chmura, G.L., Anisfeld, S.C., Cahoon, D.R. and Lynch, J.C. 2003: Global carbon sequestration in tidal, saline wetland soils. Global Biogeochemical Cycles 17, 15-27.

Curtis, J.H., Hodell, D.A. and Brenner, M. 1996: Climate variability on the Yucatan Peninsula (Mexico) during the past 3500 years, and implications for Maya Cultural Evolution. Quaternary Research 46, 37-47.

Curtis, J.H., Brenner, M., Hodell, D.A., Balser, R.A., Islebe, G.A. and Hooghiemstra, H. 1998: A multi-proxy study of Holocene environmental change in the Maya Lowlands of Peten, Guatemala. Journal of Paleolimnology 19, 139-59.

Danielsen, F., Sorensen, M.K., Olwig, M.F., Selvam, V., Parish, F., Burgess, N.D., Hiraishi, T., Karunagaran, V.M., Rasmussen, M.S., Hansen, L.B., Quarto, A. and Suryadiputra, N. 2005: The Asian tsunami: a protective role for coastal vegetation. Science 310, 643.

Dittmar, T., Hertkorn, N., Kattner, G. and Lara, R.J. 2006: Mangroves, a major source of dissolved organic carbon to the oceans. Global Biogeochemical Cycles 20, 22-34.

Ellison, A.M. and Farnsworth, E.J. 1997: Simulated sea level change alters anatomy, physiology, growth and reproduction of red mangrove (Rhizophora mangle L.). Oecologia 112, 435-46.

Feller, I.C. 1995: Effects of nutrient enrichment on growth and herbivory of dwarf red mangrove (Rhizophora Mangle). Ecological Monographs 65, 477-505.

2002: The role of herbivory by wood-boring insects in mangrove ecosystems in Belize. Oikos 97, 167-76.

Ficken, K.J., Li, B., Swain, D.L. and Eglinton, G. 2000: An n-alkane proxy for the sedimentary input of submerged/floating freshwater aquatic macrophytes. Organic Geochemistry 31, 745-49.

Garcia, E. and Holtermann, K. 1998: Calabash Caye, Turneffe Islands Atoll, Belize. In Kjerfve, B., editor, Caricomp: Caribbean coral reef, seagrass and mangrove sites. Coastal Region and Small Island Paper, 67-77.

Gischler, E. 2006: Comment on 'Corrected western Atlantic sea-level curve for the last 11,000 years based on calibrated $14 \mathrm{C}$ dates from Acropora palmata framework and intertidal peat' by Toscano and Macintyre. Coral Reefs 22: 257-270 (2003), and their response in Coral Reefs 24: 187-190 (2005). Coral Reefs 25, 273-79.

Gischler, E. and Hudson, J.H. 2004: Holocene development of the Belize Barrier Reef. Sedimentary Geology 164, 223-36.

Gischler, E. and Oschmann, W. 2005: Historical climate variation in Belize (Central America) as recorded in scleractinian coral skeletons. Palaios 20, 159-74.

Gischler, E., Hauser, I., Heinrich, K. and Scheitel, U. 2003: Characterization of depositional environments in isolated carbonate platforms based on benthic foraminifera, Belize, Central America. Palaios 18, 236-55.

Grimm, E.C. 1987: CONISS: a Fortran 77 program for stratigraphically constrained cluster analysis by the method of the incremental sum of squares. Computer and Geosciences 13, 13-35.

Halley, R.B., Shinn, E.A., Hudson, J.H. and Lidz, B. 1977: Recent and relict topography of Boo Bee patch reef, Belize. Proceedings of the 3rd International Coral Reef Symposium 2, 29-35.

Hodell, D.A., Curtis, J.H., Jones, G.A., Higueragundy, A., Brenner, M., Binford, M.W. and Dorsey, K.T. 1991: Reconstruction of Caribbean climate change over the past 10,500 years. Nature 352, 790-93.

Hodell, D.A., Curtis, J.H. and Brenner, M. 1995: Possible role of climate in the collapse of classic Maya civilization. Nature 375, 391-94. Ishshalomgordon, N., Lin, G.H. and Sternberg, L.D.L. 1992: Isotopic fractionation during cellulose synthesis in 2 mangrove species - salinity effects. Phytochemistry 31, 2623-26.

Islebe, G.A., Hooghiemstra, H., Brenner, M., Curtis, J.H. and Hodell, D.A. 1996: A Holocene vegetation history from lowland Guatemala. The Holocene 6, 265-71.

Jacob, J.S. and Hallmark, C.T. 1996: Holocene stratigraphy of Cobweb Swamp, a Maya wetland in northern Belize. Geological Society of America Bulletin 108, 883-91.

Kathiresan, K. and Rajendran, N. 2005: Coastal mangrove forests mitigated tsunami. Estuarine Coastal and Shelf Science 65, 601-606. 
Koltes, K.H., Tschirky, J.J. and Feller, I.C. 1998: Carrie Bow Cay, Belize. In Kjerfve, B., editor, CARICOMP - Caribbean coral reef, seagrass, and mangrove sites. Coastal region and small island papers 3, United Nations, 79-94.

Leyden, B.W. 1987: Man and climate in the Maya lowlands. Quaternary Research 28, 407-17.

2002: Pollen evidence for climatic variability and cultural disturbance in the Maya lowlands. Ancient Mesoamerica 13, 85-101.

Lin, G.H. and Sternberg, L.D.L. 1993: Effects of salinity fluctuation on photosynthetic gas-exchange and plant-growth of the red mangrove (Rhizophora-Mangle L). Journal of Experimental Botany 44, 9-16. 1994: Utilization of surface-water by red mangrove (RhizophoraMangle L) - an isotopic study. Bulletin of Marine Science 54, 94-102. Lovelock, C.E., Ball, M.C., Choat, B., Engelbrecht, B.M.J., Holbrook, N.M. and Feller, I.C. 2006: Linking physiological processes with mangrove forest structure: phosphorus deficiency limits canopy development, hydraulic conductivity and photosynthetic carbon gain in dwarf Rhizophora mangle. Plant Cell and Environment 29, 793-802.

Maa, C.J.W., Wang, H.J. and Lin, H.J. 2006: Impacts of catastrophic earthquakes on the insect communities in estuarine mangroves, Northern Taiwan. Biodiversity and Conservation 15, 429-41. Markgraf, V. 1993: Climatic history of Central and South America since 18,000 yr B.P.: comparison of pollen records and model simulations. In Wright, H.E., Kutzbach, J.E., Webb, T., III, Ruddiman, W.F., Street-Perrott, F.A. and Bartlein, P.J., editors, Global climates since the last glacial maximum. University of Minnesota Press, 357-85.

McCarroll, D. and Loader, N.J. 2004: Stable isotopes in tree rings. Quaternary Science Reviews 23, 771-801.

McKee, K.L. and Faulkner, P.L. 2000a: Mangrove peat analysis and reconstruction of vegetation histroy at the Pelican Cays, Belize. Atoll Research Bulletin 468, 45-58.

2000b: Restoration of biogeochemical function in mangrove forests. Restoration Ecology 8, 247-59.

McKee, K.L., Feller, I.C., Popp, M. and Wanek, W. 2002: Mangrove isotopic (delta N-15 and delta C-13) fractionation across a nitrogen vs. phosphorus limitation gradient. Ecology 83, 1065-75.

McKillop, H. 2002: Salt: white gold of the Ancient Maya. Univeristy Press of Florida.

2005: Finds in Belize document Late Classic Maya salt making and canoe transport. Proceedings of the National Academy of Sciences of the United States of America 102, 5630-34.

Pascarella, J.B. 1998: Hurricane disturbance, plant-animal interactions, and the reproductive success of a tropical shrub. Biotropica 30, 416-24.

Piou, C., Feller, I.C., Berger, U. and Chi, F. 2006: Zonation patterns of Belizean offshore mangrove forests 41 years after a catastrophic hurricane. Biotropica 38, 365-74.

Sauer, P.E., Miller, G.H. and Overpeck, J.T. 2001: Oxygen isotope ratios of organic matter in arctic lakes as a paleoclimate proxy: field and laboratory investigations. Journal of Paleolimnology 25, 43-64. Sobrado, M. and Ewe, S. 2006: Ecophysiological characteristics of Avicennia germinans and Laguncularia racemosa coexisting in a scrub mangrove forest at the Indian River Lagoon, Florida. TreesStructure and Function 20, 679-87.
Sternberg, L.D.L. and Swart, P.K. 1987: Utilization of fresh-water and ocean water by coastal plants of southern Florida. Ecology 68, 1898-905. Stuiver, M., Reimer, P.J., Bard, E., Beck, J.W., Burr, G.S., Hughen, K.A., Kromer, B., McCormac, G., Van der Plicht, J. and Spurk, M. 1998: INTCAL98 radiocarbon age calibration, 24,000-0 cal BP. Radiocarbon 40, 1041-83.

Swarzbach, A. 1999: Bibliography of sea-level change and mangroves. http://wwwscieng.murdoch.edu.au/centres/others/mangrove/ sea_level.html

Torrescano, N. and Islebe, G.A. 2006: Tropical forest and mangrove history from southeastern Mexico: a $5000 \mathrm{yr}$ pollen record and implications for sea level rise. Vegetation History and Archaeobotany 15, 191-95.

Toscano, M.A. and Macintyre, I.G. 2003: Corrected western Atlantic sea-level curve for the last 11,000 years based on calibrated C-14 dates from Acropora palmata framework and intertidal mangrove peat. Coral Reefs 22, 257-70.

Verheyden, A., Helle, G., Schleser, G.H., Dehairs, F., Beeckman, H. and Koedam, N. 2004: Annual cyclicity in high-resolution stable carbon and oxygen isotope ratios in the wood of the mangrove tree Rhizophora mucronata. Plant Cell and Environment 27, 1525-36.

Wahl, D., Byrne, R., Schreiner, T. and Hansen, R. 2006: Holocene vegetation change in the northern Peten and its implications for Maya prehistory. Quaternary Research 65, 380-89.

Whitmore, T.J., Brenner, M., Curtis, J.H., Dahlin, B.H. and Leyden, B.W. 1996: Holocene climatic and human influences on lakes of the Yucatan Peninsula, Mexico: an interdisciplinary, palaeolimnological approach. The Holocene 6, 273-87.

Woodroffe, C.D. 1995a: Mangrove vegetation of Tobacco Range and nearby Mangrove Ranges, central Belize Barrier Reef. National Museum of Natural History Smithsonian Institution, 1-35.

1995b: Response of tide-dominated mangrove shorelines in northern Australia to anticipated sea-level rise. Earth Surface Processes and Landforms 20, 65-85.

Woodroffe, S.A., Horton, B.P., Larcombe, P. and Whittaker, J.E. 2005: Intertidal mangrove foraminifera from the central Great Barrier Reef shelf, Australia: implications for sea-level reconstruction. Journal of Foraminiferal Research 35, 259-70.

Wooller, M.J., Smallwood, B., Jacobson, M. and Fogel, M. 2003a: Carbon and nitrogen stable isotopic variation in Laguncularia racemosa (L.) (white mangrove) from Florida and Belize: implications for trophic level studies. Hydrobiologia 499, 13-23.

Wooller, M.J., Smallwood, B., Scharler, U., Jacobson, M. and Fogel, M. 2003b: A taphonomic study of delta C-13 and delta N15 values in Rhizophora mangle leaves for a multi-proxy approach to mangrove palaeoecology. Organic Geochemistry 34, 1259-75.

Wooller, M.J., Behling, H., Smallwood, B.J. and Fogel, M. 2004a: Mangrove ecosystem dynamics and elemental cycling at Twin Cays, Belize, during the Holocene. Journal of Quaternary Science 19, 703-11.

Wooller, M.J., Francis, D., Fogel, M.L., Miller, G.H., Walker, I.R. and Wolfe, A.P. 2004b: Quantitative paleotemperature estimates from delta O-18 of chironomid head capsules preserved in arctic lake sediments. Journal of Paleolimnology 31, 267-74. 